\title{
Employment Status, Curriculum and College of Agriculture Graduates’ Entrepreneurial Behaviour in Cross River State, Nigeria
}

\author{
Abam Arikpo \\ Department of Curriculum/Teaching, University of Calabar, \\ PMB 1115 Calabar, Nigeria \\ Benjamin James Inyang (Corresponding author) \\ Department of Business Management, University of Calabar, \\ PMB 1115 Calabar, Nigeria \\ Tel: +234-803-377-3403_ E-mail: benji1955.unical@yahoo.co.uk
}

Received: January 29, 2011 Accepted: February 16, 2011 doi:10.5430/wje.v1n1p129

\begin{abstract}
The study investigated the difference in entrepreneurial behaviour of self employed College of Agriculture graduates vis-à-vis their counterparts who were either government employed, organised private sector employed, or unemployed. The samples (80 College of Agriculture graduates) were purposively drawn from all College of Agriculture graduates found in Cross River State, Nigeria. The Graduate Self Employed Seeking Behaviour Inventory (GSSBI) was the instrument employed in the investigation. The data gathered were analyzed using the t-test statistic. The result revealed that, there was no significant difference in entrepreneurial behaviour of College of Agriculture graduates in self employment, government employment, organised private sector employment and unemployment $(\mathrm{p}<0.05)$. The study provided some support to the notion that a realistic curriculum framework could present valuable educational content and context that would help graduates gain and reinforce appropriate entrepreneurial behaviour.
\end{abstract}

Keywords: Entrepreneurial behaviour, Self-employed, Employment status, Agricultural programmes, Curriculum, Agriculturalist, Nigeria

\section{Introduction}

Though Agriculture has been the main stay of the Nigerian economy, formal training or education in agriculture came into being in the country, in the 1920s. This followed the establishment of College of Agriculture in Moor Plantation, Ibadan (1921), and Samaru (1927). In addition to these was the School of Animal Health, established near Kaduna. The number of these schools, however, increased with the 1954 division of the country into three regions. This was because; first a need arose for a school of Agriculture to be established at Umudike (1955) in the Eastern Region to complement the effort of those in the Northern and Western Regions. Secondly, another school of Agriculture was opened at Akure to give training to agric extension workers; while in Vom the Federal Government opened an institute to train livestock superintendents and laboratory technicians. Other Agricultural staff training institutions included the Cooperative Training College, Ibadan; the Irrigation School, Kaduna; and several other provincial farm training centres and School of forestry, veterinary science (Okorie, 2001; Arikpo, 2004).

In 1967 when once again the country was reconstituted from 4 regions to 12 states, the establishment of various schools of Agriculture precipitated the different states. This followed the opening of an extension training centre in Benin at the creation of the Mid-western region. The centre offered short term courses and in-service training programmes (Okorie, 2001).

No matter the generation of these schools, their purpose was definite: (i) provide European trained agricultural assistants who were in acute short supply (Okedara, 1984; Fafunwa, 1979; Ikpe, 2000) at the time; and (ii) cater for the manpower shortage bound to face the country at independence (Sir Eric Ashby Commission, 1959, 1960) as quoted in Adeyemo (1997).

These job opportunities, however, remained open to graduates of these schools until mid-1980. Thereafter, many of them went unemployed. The public sector orientation of their curriculum content and learning experiences could not allow their graduates, who were unable to secure jobs in government, to be self employed. The situation became even worse 
because their school curriculum was hinged on perennialism. It emphasised the discipline of the mind through the study of selected excellent subjects. For instance, admission into their programmes required credit passes at General Certificate of Education (G.C.E.) ordinary level in Mathematics, Agricultural Science and English Language, or a good secondary school education (Makinde and Alao, 1987). They ignored the interest of the candidates and disregarded the impact of the Nigerian environment on agricultural education. Their emphasis was culturation of intellectual virtues through permanent studies (Amadi, 1991).

Invariably, the psychological theory which underlay the school curriculum was behaviouralim, or associationism. By this psychological theory, the curriculum of these schools sought to educate candidates or their students to become what they are not. The curriculum offered an ideal character to which it attempts to mould each candidate or student. The curriculum, therefore, postulated each of its candidates or students an energy system, which attempted to maintain equilibrium by responding to other energy systems with which it interacted through the sense organs. This energy systems were the terminology, specific fact, concepts and principles, methods and procedures, written material, graphs, maps, numerical data, problem situations, factorial information, problem solving skills, critical thinking skills, scientific thinking skills, laboratory skills, performance skills, communication skills, computational skills, social skills, social attitudes, scientific attitudes, and social adjustments (Gronlund, 1976) which the candidates or students responded to in books, teachers, classrooms, laboratories, and libraries than the native environment. These became their entire beings: their rationality, feelings and motivation (Amadi, 1991).

To this end candidates' or students' knowledge of agriculture remained attributable to academic ability than attitudes. So that what they knew of agriculture was not what started as early as their infant home age (Briggs, 1959; Akinbole, 1999). Even where the candidates had acquired such an attitude, it became decreased or decreased during school life as a result of certain conditions. Such conditions Akinbole (1993), enumerated to include: (i) the teacher's personality (whether it was liked or disliked by the candidate or student); (ii) the attitude of the teacher towards the courses offered by the school; (iii) parental influence and (iv) the teacher's method of organising and presenting instruction to students or candidates (Akinbole, 1999).

Consequently, interest based learning experiences, individual differences, and meaningful learning activities that should make for self employment seeking behaviour were destroyed in the students. They became replaced by opportunities for students to interact with materials, ask questions, discuss answers, teach peers, critique submissions, recall information, etc. These did not make for cognitive thinking, which could help graduates of schools of Agriculture self improve their living standards particularly at the instance of retrenchment and unemployment threats (Okpala and Adeoye, 1999; Akinbole, 1999).

To remedy this situation, the Nigerian government under the National Directorate of Employment (NDE), which was launched in 1987, introduced an out of school agricultural programme. Under this programme, unemployed graduates of agriculture were motivated by government to practice their filed. They were allocated 5 hectares of land and granted N11,500 loan to facilitate the practice (Philips and Ajakaye, 1991). Other programmes of allied intentions were those of the Directorate of Foods, Roads and Rural Infrastructure (DFFRI), the Better Life Programme (BLP); the Nigerian Agricultural Insurance Company (NAIC); the Commodity Exchange Market (COMEX); Agricultural Development Projects (ADP) and River Basin Development Authorities (RBDA), the Small Holder Farm Credit Scheme; the National Agricultural Land Development Authority (NALDA), the Nomadic and Migrant Fishermen Education, etc. (Arikpo, 2005).

Therefore, this study sought to find out if prior to these programmes, the schools of Agricultural curricula offered little or nothing for the entrepreneurial behaviour of their graduates.

\section{Purpose of the Study}

The study was carried out to determine the impact of agricultural education on the entrepreneurial behaviour of school of Agriculture graduates in, Cross River State. Based on the problem and the foregoing background, the following hypotheses were formulated and tested:

$\mathbf{H o}_{1}$ : There is no significant difference in the mean scores of self employed and government employed College of Agriculture graduates.

$\mathbf{H O}_{2}$ : There is no significant difference in the mean scores of self employed and organised private sector employed College of Agriculture graduates.

$\mathbf{H O}_{3}$ : There is no significant difference in the mean score of self employed and unemployed College of Agriculture graduates. 


\section{Materials and Methods}

The study employed an ex-post facto research design. This design was appropriate because the variables of interest already existed in the individuals of concern and situation studied. So, the researcher had no direct control over the independent variables.

\subsection{Sample and sampling technique}

The sample consisted of 80 College of Agriculture graduates. These were selected from a population of all College of Agriculture graduates in Cross River State. 29(36.25\%) of these were self employed; 28(35.0\%) government employed; 10(12.5\%) private sector employed, and 13(16.25\%) unemployed. The break down is shown in the Table 1.

\section{$<$ Table 1about here>}

This sample was selected through inspection and selection of registered names and addresses of business entrepreneurs in books of Cross River State Ministry of Commerce and Industry and National Directorate of Employment, Federal Secretariat Complex, Calabar; and various friendship networks, opportunity and snow balling techniques.

\subsection{Instrumentation}

One instrument was used in the study. This instrument was, the Graduate Self Employment Seeking Behaviour Inventory (GSSBI). The instrument was designed and validated by the researchers. However, it was an adaptation of that developed by Hitchin (1996). It was designed to elicit the opinion of College of Agriculture graduates on the immediate possibility of using the knowledge, attitude, skill and experience acquired from college to either serve in a variety of professions and occupations; private services to their society where occasion demands; or create jobs for themselves. In all, the instrument consisted of 20 items based on aspects of self employment, government employment, organised private sector employment and unemployment. Samples were expected to tick Very Difficult, Difficult, Easy, Fairly Easy, or Very Easy, in the column against statements under each of this employment status. It was scored by ascribing 5, 4, 3, 2, and 1 to Very Easy, Easy, Difficult, Very Difficult and Fairly Difficult respectively. Cronbach alpha was used to estimate its reliability index and this yielded 0.81 alpha value.

\subsection{Procedure}

After the purposive or rational selection of the sample, the investigators visited the Cross River State Ministry of Commerce and Industry; the National Directorate of Employment, Federal Secretariat complex, Calabar; homes; Christian Fellowship centres, secondary schools and business premises. This was to discuss the purpose of the study with their heads; obtain permission to identify and select members to their sample; and as well administer their questionnaire on them. Many of the homes, Christian fellowship centres, business premises, and work places were relatively far apart, besides being scattered across the state. So, the investigators employed the services of 12 research assistants. The 12 research assistants were graduates of Colleges of Agriculture (COA) who already have fair experience and knowledge in the administration of questionnaires. Yet the investigators briefed the research assistants on the specific requirements and demands of the questionnaire and its method of respondents' checking. This the investigators did for a given period of time before their administration of the questionnaire started. The investigators, however, first had to administer the questionnaire on forty (40) samples before it large scale administration. The scores from this initial administration were used to facilitate its trial testing and comparison of findings after the overall investigation had been done. After this initial administration, the investigators made the questionnaire available to the research assistants who helped to make its large scale administration on all samples. No assistance was given to respondents, except in the reading of instructions to the questionnaire.

The investigators scored all responses to the questionnaire. Each positive response attracted higher marks; while each negative response attracted lower marks. The maximum mark obtainable of the questionnaire was 100 . Data collected were computer analysed.

\section{Results}

Since only two groups were involved in each hypothesis, t-test was computed to test each of such affected hypothesis generated for the study. The results are presented in the Table below:

\subsection{Hypothesis 1}

There is no significant difference in the means score of self employed and government employed College of Agriculture graduates.

<Table 2 about here $>$

Table 2 shows that self employed College of Agriculture graduates obtained a higher mean score $(x=66.28)$ than their 
government employed counterparts $(\mathrm{x}=62.50)$ on entrepreneurial behaviour, giving a mean difference of 3.78. However, the mean difference is not significant ( $\mathrm{t}-\mathrm{cal}=1.24$; $\mathrm{t}$-crit $=1.960 ; \mathrm{df}=55 ; \mathrm{P}<0.05$ ). So, null hypothesis $\mathrm{H}_{1}$ is retained. Since self employed and government employed College of Agriculture graduates do not differ significantly in their entrepreneurial behaviour. The hypothesized similarity between self employed and government employed College of Agriculture graduates in entrepreneurial behaviour is not rejected, either.

\subsection{Hypothesis 2}

There is no significant difference in the mean scores of self employed and organized private sector employed College of Agriculture graduates.

$<$ Table 3 about here $>$

Table 3 shows that the organised private sector employed College of Agriculture graduates obtained a higher mean score $(x=74.00)$ than the self employed College of Agriculture graduates $(x=66.28)$. Notwithstanding, the mean difference is 7.72, and it is not significant ( $t$-cal=-1.01' $t$-crit $=1.960 ; \mathrm{df}=37 ; \mathrm{p}<0.05$ ), so null hypothesis $\mathrm{HO}_{2}$ is retained. This is because since the critical-t is higher than the cal-t, self employed and organised private sector employed College of Agriculture graduates do not differ significantly in their entrepreneurial behaviour.

The hypothesised similarity between self employed and organised private sector employed college of Agriculture graduates in entrepreneurial behaviour is not rejected.

\subsection{Hypothesis 3}

There is no significant difference in the mean scores of self employed and unemployed College of Agriculture graduates.

$<$ Table 4 about here>

The result on Table 4 shows that unemployed College of Agriculture graduates obtained a higher mean score $(\mathrm{x}=77.50)$ than their counterparts $(x=66.28)$ on entrepreneurial behaviour. However, the mean difference is 11.22 , and it is not significant (t-cal=-1.51; t-crit $=1.960 ; \mathrm{df}=40 ; \mathrm{p}<0.05$ ). Null hypothesis $\mathrm{H}_{3}$ is not rejected. It is retained. From the findings, self employed and unemployed College of Agriculture graduates do not differ significantly in their entrepreneurial behaviour. Thus, the hypothesised similarity between the self employed and unemployed College of Agriculture graduates in entrepreneurial behaviour is not rejected.

\section{Discussion and Conclusion}

The main purpose of this study was to investigate the difference if any, in the entrepreneurial behaviour of self employed versus government employed, organised private sector employed and unemployed College of Agriculture graduates. Available data from the study have revealed no significant differences in entrepreneurial behaviour of either the self employed or the government employed, the organised private sector employed and the unemployed College of Agriculture graduate. This led to the non rejection of null hypotheses $\mathrm{HO}_{1}, \mathrm{HO}_{2}$, and $\mathrm{HO}_{3}$ tested in the study; signifying that employment status is not a significant factor in the display of entrepreneurial behaviour by College of Agriculture graduates. Thus, self employed, government employed, organised private sector employed and unemployed College of Agriculture graduates could be exposed to similar conditions without giving any preferential treatment.

The result on the other hand, provides some degree of assurance on the efficacy of the College of Agriculture curriculum to offer its recipients potent content and context strategies, which formally enhance in them entrepreneurial behaviour. Studies elsewhere (Arikpo, 2005; Goldstein and Turner, 1996; and Makinde and Alao, 1987), have actually demonstrated that the College of Agriculture could foster lasting entrepreneurial behaviour in its recipients and as well ensure more stable employment opportunities.

Perhaps some of the advantages that College of Agriculture graduates enjoy is that the College curriculum offers them opportunities to organise to meet more of their own needs for themselves; develop the will and the competence to manage their own affairs; and ask them questions, which intend to help them think more systematically and relevantly than they would otherwise do.

Graduates of Colleges of Agriculture are to, by the curriculum orientation of the institution they attended, be individuals who would obtain tangible results from their academic achievement. They would need to have access to work with things like tools, machines, or animals in the field rather than with human beings or ideas. The curriculum is, thus, seen to be realistic, with its behavioural outcomes being those that cause their recipients to be described honest, straight-talking, practical, modest, frugal and conforming. Its learning experiences remain those which demand its recipient to engage in manipulation of the physical environment, manual labour and activities (Makinde and Alao, 1987; Jones and Jones, 1991). Moreover, such a curriculum provides its recipient's opportunities to observe, imitate, practice, 
and adopt, or adapt performances by an expert. This situation encourages its recipients to (i) take a voluntary life relationship with a practising agriculturist; (ii) grow unto the measure of the stature of the fullness of the practising agriculturist; (iii) reproduce or accept the life of the observed practising agriculturist unto himself or herself and (iv) voluntarily surrender himself or herself to the knowledge, attitudes, skills, experiences or practices of the mentor agriculturist, at the instance of unemployment (Akanni, 1997; Amadi, 1990, Urevbu, 1985).

Hence, the curriculum besides being realistic is a life-long process, or a systematic and cumulative way of making a College of Agriculture student to, in his or her capacity as a trainee, an apprentice, raw material, or disciple, be like the renowned agriculturist. Be that as it may, what this investigation has shown within its own limits is that College of Agriculture graduates demonstrated better entrepreneurial behaviour, irrespective of their employment status.

Since the present investigation is limited to only one tertiary institution type, it might be necessary to determine the effect of employment status on entrepreneurial behaviour of either University, Polytechnic or College of Education graduates, too. This will help determine which of the tertiary institution graduates' entrepreneurial behaviour will be more difficult for, or disliked by either sole proprietorship, government, organised private sector, or jobless employment status.

\section{Summary of study}

In the light of the entire results and associated discussion, the investigators share the view that educational policies and practices should, as they affect the college of Agriculture curriculum, ensure they bring its recipients through a training process, exposure and discipline administered by a practising agriculturist with a view to making them become like himself or herself. To this end, the curriculum produced by such policies and practices would need to feature a master-apprentice or a teacher-learner relationship which has a predetermined content, context and behavioural objective between the learner and the practising agriculturist. Communication is interpersonal. It is the exchange of ideas and information between the master and his or her apprentice. In this case neither the master nor the apprentice keeps his or her ideas to himself or herself. Both share them directly with one another, signs of exchange can be observed. Interpersonal communication helps to break the barriers of formal relationships and generate warmth and harmony essential for increased self enterprise (James, Ode, \& Soola, 1992 and Inyang, Oden \& Esu, 2003). The investigators hope that the implementation of these recommendations would result into seeing every student of a College of Agriculture as: (i) an apprentice or a raw material that has the potential of becoming like every other practising agriculturist (ii) one who only needs to pass trough training, periods of instruction intermingled with times of practical exposure guided by the practising agriculturist, who is the mentor or master, or another person appropriated by the mentor or master, the agriculturist; and (iii) one who relates very closely with the mentor or master, keenly watching him and following after him one step after the other with the hope of being like him, the mentor or master agriculturalist.

\section{References}

Adeyemo, A. J. (1997). The demand for higher education and employment opportunities in Nigeria. Ibadan: Foundation for Entrepreneurship Development.

Akanni, G. (1997). Becoming like Jesus: God's key to abundant living. Gboko: Peace House Publishing.

Akinbole, O. (1999). Sex differences in the cognitive and affective outcomes in social studies of primary school pupils, African Journal of Educational Research, 5(1): 34-38.

Amadi , L. E. (1990). Principles of curriculum development. Uyo: Legacy.

Arikpo, P. A. (2005). Self-employment seeking behaviour of graduates in Cross River and River States, Nigeria. Unpublished Ph.D Thesis, University of Ibadan, Ibadan

Briggs, J. B. (1959). Attitude to arithmetic-number anxiety. Education Research, 1(3): 6-21. doi:10.1080/0013188590010301, http://dx.doi.org/10.1080/0013188590010301

Fafunwa, A. B. (1979). History of education in Nigeria. London: George Allen and Unwin.

Goldstein, M. \& Turner, P. (1996). Banking crisis in emerging economies: Origins and policy options, E.U Economic Pape 46. Bank for International Settlements, Monetary and Economic Department.

Gronlund, N. E. (1976). Measurement and evaluation in teaching. New York: Macmillan.

Hitchin, P. (1996). Getting your first job. Plymouth: How to Books. 
Ikpe, U. N. (2000). An introduction to vocational business education in Nigeria. Calabar: Baaj International Company. Inyang, B. J., Oden, S. N. I. \& Esu, B. B. (2003). Essentials of business communication. Calabar: Merb Publishers.

Jones, G. \& Jones, R. (1991). Naturally gifted: A christian perspective on personality, gifts and abilities. London: Scripture Union.

Makinde, O. \& Alao, K. (1987). Profile of career education. Ibadan: Signal Educational Services.

Okedara, J. T. (1984). Employment status of University of Ibadan graduates 1950-1971. Ibadan: Ibadan University Press.

Okorie, J. U. (2001). Vocational industrial education. Bauchi: League of Researchers.

Okpala, P. N. \& Adeoya, F. A. (1999). Assessment procedure, student cognitive style and gender as determinants of physics performance of cognitive level of University. African Journal of Educational Research, 5(1): 39-50.

Philips, A. O. \& Ayakaye, D. O. (1991). Nigerian economic policy and development 1988-1989. Ibadan: NISER.

Urevbu, A. (1985). Curriculum studies. Lagos: Longman Nigeria.

Table 1. A table of the employment status/number/percentage of college of Agriculture graduates used in the study

\begin{tabular}{|l|c|c|c|c|c|}
\hline Employment status & Self employed & $\begin{array}{c}\text { Government } \\
\text { Employed }\end{array}$ & $\begin{array}{c}\text { Private sector } \\
\text { Employed }\end{array}$ & Unemployed & Total \\
\hline Number & 29 & 28 & 10 & 13 & 80 \\
\hline Percentage (\%) & 36.25 & 35.0 & 12.5 & 16.25 & 100 \\
\hline
\end{tabular}

Table 2. $\quad$ t-test comparison of mean score of self employed and government employed College of Agriculture graduates

\begin{tabular}{|l|c|c|c|c|c|c|c|}
\hline $\begin{array}{l}\text { Employment } \\
\text { Status }\end{array}$ & $\mathrm{N}$ & Mean & SD & Df & t-cal & t-crit & P \\
\hline $\begin{array}{l}\text { Self } \\
\text { Employed }\end{array}$ & 29 & 66.28 & 8.14 & & & & \\
\hline & & & & 55 & 1.24 & 1.960 & NS \\
\hline $\begin{array}{l}\text { Government } \\
\text { Employed }\end{array}$ & 28 & 62.50 & 14.00 & & & & \\
\hline
\end{tabular}

N.S = Not significant at p.05 
Table 3. T-test comparison of means scores of self employed and organized private sector employed College of Agriculture graduates

\begin{tabular}{|l|l|l|l|l|l|l|l|}
\hline $\begin{array}{l}\text { Employment } \\
\text { Status }\end{array}$ & $\mathrm{N}$ & Mean & SD & Df & t-cal & t-crit & $\mathrm{P}$ \\
\hline $\begin{array}{l}\text { Self } \\
\text { Employed }\end{array}$ & 29 & 66.28 & 8.14 & & & & \\
\hline & & & & 37 & -1.01 & 1.960 & $\mathrm{NS}$ \\
\hline $\begin{array}{l}\text { Organised private sector } \\
\text { Employed }\end{array}$ & 10 & 74.00 & 23.74 & & & & \\
\hline
\end{tabular}

N.S = Not significant at p.05

Table 4. t-test comparison of means scores of self employed and unemployed College of Agriculture graduates

\begin{tabular}{|l|l|l|l|l|l|l|l|}
\hline $\begin{array}{l}\text { Employment } \\
\text { Status }\end{array}$ & $\mathrm{N}$ & Mean & SD & Df & t-cal & t-crit & P \\
\hline Self employed & 29 & 66.28 & 8.14 & & & & \\
\hline & & & & 40 & -1.51 & 1.960 & NS \\
\hline Unemployed & 13 & 77.50 & 26.30 & & & & \\
\hline
\end{tabular}

N.S = Not significant at p.05 